\title{
Dispositivos inalatórios e Trigger Tool - Uma nova perspectiva em pediatria?
}

\author{
Raphael Fernando Boiati ${ }^{1}$, Rafael Portugal de Lima ${ }^{2}$, Ana Paula Meneses ${ }^{2}$, Liliane Soares ${ }^{3}$, \\ Janaína Cecília Oliveira Villanova Konishi ${ }^{4}$
}

\section{Resumo}

Com o objetivo de melhorar a segurança do paciente, como regra básica deve ser elaborado documentos, guias de prática clínica, estudos científicos, elaboração de novas práticas assistenciais, tecnológicas e farmacológicas, além de métodos de aprendizagem diversos.

O processo de informação e aprendizagem dos pacientes, bem como de seus familiares, é a base da experiência, priorizando a comunicação entre o paciente, familiares e toda a equipe multidisciplinar, priorizando cuidados cada vez mais seguros.

Há 4000 anos, a inalação de anticolinérgicos naturais já eram utilizados por via inalatória. Somente na década de 30, modernos estudos iniciaram com a utilização da adrenalina, e na década de 50, os primeiros nebulizadores de jato aerossol dosimétrico com CFC foram lançados no mercado.

Os medicamentos administrados pela via inalatória propiciam uma maior concentração e menor risco de efeitos adversos.

Enfermidades respiratórias geram impactos diretos na saúde da população de forma social e economicamente negativos, gerando reduções na qualidade de vida, comprometimento das atividades diárias e elevados custos direto e indiretos por visitas a salas de emergência, hospitalizações e consultas ambulatoriais não agendadas, além do absenteísmo na escola e no trabalho.

Visando este impacto negativo, implantamos no Hospital Infantil Sabará o Programa de Educação ao Paciente em Uso de Dispositivo Inalatório, que engloba toda a equipe de farmácia do hospital, capacitados e empenhados em ensinar a técnica de inalação de forma adequada.

Programas de educação, tanto para crianças quanto para adultos, possuem importante papel no treinamento de pacientes para a aquisição da técnica correta de utilização dos dispositivos inalatórios.

Diversos trabalhos no mundo inteiro, descrevem em seus estudos relatos sobre plano educacional. Arora P et. al. 2014 descrevem que o padrão educacional, socioeconômico, idade e

\footnotetext{
${ }^{1}$ Farmacêutico Clínico Hospital Infantil Sabará, Mestre em Ciências da Reabilitação Universidade Nove de Julho. Email: raphael.boiati@hotmail.com

${ }^{2}$ Farmacêutico Clínico Hospital Infantil Sabará.

${ }^{3}$ Farmacêutica Hospital Infantil Sabará, Gerente de Suprimentos/Apoio.

${ }^{4}$ Docente Universidade Federal de Alegre - ES.
} 
duração no uso, influenciam diretamente no número de erros cometidos pelos usuários no momento da utilização do dispositivo inalatório. A aplicação do plano educacional reduziu em 43,7\% os erros cometidos pelos usuários.

Alguns pesquisadores avaliaram prospectivamente 93 pacientes com DPOC ou asma que nunca haviam feito uso de medicação inalatória por inalador dosimetrado e, após 10 dias da primeira aplicação, somente $48,4 \%$ dos pacientes realizaram a técnica de uso do dispositivo corretamente (Sandrini A. et al. 2001).

Analisando os resultados publicados, o plano de educação aos pacientes, além dos familiares é de extrema importância visando a melhora da patologia, e consequentemente a melhora da qualidade de vida dos pacientes usuários desta via de administração.

Quando pensamos em tratamentos farmacológicos, uma terapia personalizada envolve, além do diagnóstico correto, a escolha de um fármaco na dose ótima durante um período adequado, o cálculo da dose para cada indivíduo e, a administração pela via apropriada. Ao prescrever e dispensar um medicamento, médicos e farmacêuticos - corresponsáveis - devem considerar que o paciente receberá toda a dose requerida para o efeito terapêutico, durante o tempo previsto, pela via correta, com segurança e conforto, otimizando a farmacoterapia.

A segurança é um assunto de importância crescente que está na agenda dos cuidados ao paciente. Umadasiniciativastomadasem2003 foi o estabelecimento de metas para a segurança dos pacientes, incluindo as direcionadas aos medicamentos a serem cumpridas pelos hospitais acreditados pela The Joint Commission International, agência Norte-Americana de acreditação de serviços e sistemas de saúde que possui como principais objetivos avaliar, monitorar e identificar elementos relacionados com a segurança do paciente.

Várias ferramentas usando "triggers tool" ou "ferramenta de gatilho" têm sido utilizadas na monitorização das RAM. Este método consiste na identificação de medicamentos, chamados de gatilhos que podem identificar uma RAM, e, a partir deles é feita a análise comparando com literaturas sobre a RAM que pode ou não ser confirmada, isto é feito através da revisão do prontuário do paciente. O aumento de reações adversas a medicamentos (RAM) é uma importante causa de admissão e prolongamento de permanência hospitalar.

Este estudo tem o objetivo de avaliar através da utilização do método "trigger tool, o número de RAM identificadas após a utilização de medicamentos. O método utilizado foi uma análise de prontuários de pacientes que fizeram uso de algum medicamento considerado "trigger tool” no período de março 2013 a março de 2014, com o intuito de identificar possíveis RAM, comparou-se também com o método de notificação voluntária.

Comparando os métodos: a análise pelo método “trigger tool” gerou 83 notificações, enquanto o outro método (notificação voluntária) gerou 8 notificações, 69\% das RAM ocorreram em pacientes com idades entre 0 e 6 anos e 31\% ocorreram em crianças e adolescentes com idades entre 7 e 18 
anos. Antimicrobianos foi a classe mais relacionada com as suspeitas de RAM em 30\% e em $60 \%$ pela notificação voluntária.

Conclui-se que o método "trigger tool" mostrou-se eficiente na busca e monitoramento de RAM.

Palavras chave: Dispositivos Inalatórios; Educação; Trigger tool; Reação adversa; Pediatria

Boiati, Raphael Fernando; de Lima, Rafael Portugal; Meneses, Ana Paula; Soares, Liliane, Konishi, Janaína Cecília Oliveira Villanova. "Dispositivos inalatórios e Trigger Tool - Uma nova perspectiva em pediatria?", in Anais do 2o. Congresso Internacional Sabará de Especialidades Pediátricas 


\title{
Inhalers and Trigger Tool - A new perspective in pediatrics?
}

\author{
Abstract: \\ With the goal of improving patient safety, as a basic rule documents, practice guidelines, scientific \\ studies, development of new care, technological and pharmacological practices should be developed, \\ as well appropriate as methods of learning. \\ The process of information and learning of patients and their families, is the basis of \\ experience, prioritizing communication between the patient, family and the entire multidisciplinary \\ team, prioritizing increasingly safe care.
}

Since 4000 years ago, the natural inhalation of anticholinergics are used by inhalation. Only in the 30s, modern studies began with the use of adrenaline, and in the 50s, the first jet nebulizers dosimetric aerosol with CFC was launched.

Drugs administered by inhalation provide a higher concentration at the site of action, and a lower risk of adverse effects.

Respiratory diseases generate direct impacts on population health of socially and economically negative fashion, causing reductions in quality of life, impairment of daily activities and high direct and indirect costs for emergency room visits, hospitalizations and unscheduled outpatient visits, in addition to absenteeism at school and at work.

Looking this negative impact, implemented in the Children's Hospital Sabará the Patient Education Program on Use of Inhaled device that encompasses the entire staff of the hospital pharmacy, trained and committed to teaching inhaler technique properly.

The education programs for both children and adults, play an important role in training patients to acquire the correct technique for using inhalers.

Several papers worldwide, describe in their reports studies on educational plan. Arora P et. al. 2014 describe the educational standard, socioeconomic, age and duration of use, directly influence the number of mistakes made by users when using the inhaler device. The implementation of the educational plan reduced by $43.7 \%$ the mistakes made by users.

Some researchers prospectively evaluated 93 patients with COPD or asthma who had never used inhaled medication by metered-dose inhaler, and 10 days after the first application, only $48.4 \%$ of the patients undergoing technical, used the device correctly (Sandrini A. et al., 2001).

Analyzing the results published, the education plan for patients, apart from family is of utmost importance aiming the improvement of the condition, and consequently improving the quality of life of patients using this route of administration.

When we think of pharmacological treatments, a personalized therapy involves, besides the correct diagnosis, the choice of a drug at the optimal dose for an appropriate period, the dose 
calculation for each individual and the administration by any appropriate means. To prescribe and dispense a drug, doctors and pharmacists - share responsibility - consider that the patient will receive the entire dose required for the therapeutic effect during the allotted time, the correct way, with safety and comfort, optimizing pharmacotherapy.

Security is an issue of growing importance, and is on the agenda of patient care. One of the initiatives taken in 2003, was setting goals for patient safety, including targeted drug to be met in hospitals accredited by The Joint Commission International, the US agency for accreditation of health services and systems that has as main objectives to assess, monitor and identify elements related to patient safety.

Various tools using "trigger tool" have been used in the monitoring of ADR. This method consists in the identification of drugs, called triggers that can identify a ADR, and from comparing them with the literature on the ADR that can not be confirmed or analyzed, this is done by reviewing the patient's medical record. The increase in adverse drug reactions (ADR) is a major cause of admission and prolonged hospital stay.

The study was conducted to evaluate the method by using "trigger tool, the number of ADR identified after use of medicines. The method used was an analysis of records of patients who used any drugs considered "trigger" from March 2013 to March 2014, in order to identify possible ADR, also compared with the method of voluntary reporting.

Comparing methods, the analysis by using "trigger tool" produced 83 notifications, while the other method (voluntary reporting) generated 8 notifications, 69\% of ADR occurred in patients aged between 0 and 6 years and 31\% occurred in children and adolescents aged between 7 and 18 years. The antimicrobials are more related to the suspected ADR in $30 \%$ and $60 \%$ for the voluntary reporting class.

This study suggest that the "trigger tool" proves efficient in finding and monitoring of ADR.

Keywords: Inhalation devices; Education; Trigger tool; Adverse reaction; Pediatrics. 


\section{Referências}

Arora P, Kumar L, Vohra V, Sarin R, Jaiswal A, Puri MM, Rathee D, Chakraborty P. Evaluating the technique of using inhalation device in COPD and Bronchial Asthma patients. New Delhi: India. Nat Instit TB and Resp Disea, 2014.

Coelho ACC, Souza-Machado A, Leite M, Almeida P, Castro L, Cruz CS et al. Use of inhaler devices and asthma control in severe asthma patients at a referral center in the city of Salvador, Brasil. $\mathbf{J}$ Bras Pneumol. 2011; 37(6): 720-728.

Lima RP, Meneses AP, Soares L, Villanova JCO, Boiati RF. Busca a reações adversas a medicamentos: Trigger Tool uma ferramenta nova e eficaz? In press. 2014.

(Sandrini A, Jacomossi A, Farensin SM, Fernandes AL, Jardim JR. Aprendizado do uso do inalador dosimetrado após explicação por pneumologista. J Pneumol. 2001;27(1):7-10.

Yildiz F. Importance of inhaler device use status in the controlo $f$ asthma in adults: The asthma inhaler treatmente study. Respiratory Care. 2014:59(2). 